\title{
Standing Litter and Litterfall Pattern in Dry Tropical Forests of Achanakmaar-Amarkantak Biosphere Reserve (AABR), India
}

\author{
H. Darro and S. L. Swamy* \\ College of Agriculture, Katghora-Korba, Indira Gandhi Agricultural University (CG), India \\ *Corresponding author
}

\author{
A B S T R A C T
}

\begin{tabular}{|l|}
\hline Ke y w o r d s \\
Litter crop, Litter \\
dynamics, \\
Structure, Litter \\
components, \\
Tropical dry forests \\
\hline Article Info \\
\hline $\begin{array}{l}\text { Accepted: } \\
\text { 15 March } 2020 \\
\text { Available Online: } \\
10 \text { April 2020 }\end{array}$ \\
\hline
\end{tabular}

The present study was conducted to quantify the standing litter crop and litter fall production under dry tropical forests in buffer zone of Achanakmaar-Amarkantak Biosphere Reserve (AABR). Five major forest types viz., mixed forest, Sal Mixed Forest, Mixed Teak forest, Teak Mixed forest and Bamboo brakes were identified after floristic survey in the study area. Standing litter crop was recorded by randomly laying three $0.5 \times 0.5 \mathrm{~m}$ sub quadrates on forest floor in each marked sample quadrate $(20 \times 20 \mathrm{~m})$ of a forest type. In total, standing litter was collected in 15 sample plots (3 locations within quadrate x 5 quadrates). Litter fall transferred to the forest floor was measured in different seasons by randomly laying three litter traps (each $50 \times 50 \times 50 \mathrm{~cm}$ size) in each sample plot under different forest types. In total, litter fall was also recorded in 15 sample plots similar to standing litter. Results revealed that total standing litter varied from $0.48 \mathrm{Mg} \mathrm{ha}^{-1}$ to $2.49 \mathrm{Mg} \mathrm{ha}^{-1}$ in different forest types. It was highest in Mixed Forest and lowest in Bamboo Brakes. The standing litter in different forest types was in the order: Mixed Forest > Mixed Sal Forest $>$ Mixed Teak Forest $>$ Teak Mixed Forest $>$ Bamboo brakes. The litter mass contributed by different components was in the order: leaf $>$ wood $>$ bark. For total standing litter, the leaf litter contributed from $52.1 \%$ to $91.7 \%$, wood from $5.8 \%$ to $38.1 \%$ and bark litter from $1.4 \%$ to $12.1 \%$. The total annual litter fall in different vegetation types ranged from 0.86 to $3.52 \mathrm{Mg} \mathrm{ha}^{-1} \mathrm{yr}^{-1}$. It was highest in Mixed Sal Forest, while lowest in Bamboo Brakes. Among three seasons, the litter fall was highest in winter followed by summer and rainy seasons. Leaves contributed to maximum followed by wood and bark for total litter fall in different seasons. For total litter fall, in summer it ranged from $29.2 \%$ to $41 \%$, winter from $34.9 \%$ to $41 \%$ and rainy from $23.3 \%$ to $31.2 \%$. The study discussed role of management practices for improving the litter production in degraded forest types in buffer zone of AABR.

\section{Introduction}

Litterfall is a fundamental process of nutrient cycling and represent significant component of net primary production of forest ecosystem. The spatiotemporal patterns of litter fall therefore needs to be quantified for estimating net productivity and nutrient budgets of ecosystem. The analysis of litter quantity, quality and its rate of decomposition are highly important for understanding processes energy flow, primary productivity, nutrient pools and fluxes in forest ecosystems (Tang $e t$ al., 2010).

In tropical forest ecosystems, litter dynamics play vital role on soil organic matter and microbial population, which are essential for maintaining ecosystem health (Nakagawa $e t$ al., 2019). However, the increasing natural 
and anthropogenic disturbances are causing the degradation of tropical forests and altering the dynamics of litter production and nutrient cycling.

As litter production depends on stand composition, structure, growth rate and productivity. Vegetation composition is the driving factor in influencing litter production within a climate zone (Tang et al., 2010). Numerous studies have reported that litter fall productivity is higher in diverse mixed stands than in monoculture stands (Tang et al., 2010; Yadav, 2018; Wang et al., 2019). The total litter fall in mature forests is different from monoculture. Litter fall also vary with vegetation type and edapho-climatic conditions. The litter production dramatically increases during dormant and dry seasons in tropics. In the current scenario of global warming and climate change, maintaining vegetation and soil $\mathrm{C}$ pools is relevant for mitigating the negative effects. The frequent droughts and erratic rainfall as consequence of warming significantly influence litter crop production.

The low quality and poor litter production under adverse conditions could disturb flow of nutrients between plant and soil interface, thereby increase the degradation and vulnerable to climate change (Nakagawa et al., 2019). It becomes imperative to monitor and understand the productivity and litter dynamics in disturbed and regenerating habitats in the tropical forests is very much warranted for sustainable management of tropical forests.

Limited studies were conducted on litter production in undisturbed dry tropical forests of Central India and studies are lacking especially in disturbed forests and plantations (Yadav, 2018). Such information is vital for maintaining the structure and functioning of an ecosystem so that flow of ecosystem services could not be interrupted. Therefore, the present study was conducted to quantify the standing litter and litter fall in different vegetation types of dry tropical forest of Achanakmaar-Amarkantak Biosphere Reserve, India.

\section{Materials and Methods}

\section{Study site}

The study was carried out in Khuriya Forest Range of Mungeli Forest Division comprising buffer zone of Achanakmaar Amarkantak Biosphere Reserve (AABR), Chhattisgarh India. It is located between $21^{\circ} 48^{\prime} 35^{\prime \prime}$ to $22^{0}$ $40^{\prime} 30^{\prime \prime}$ North latitudes and $81^{\circ} 29^{\prime} 45^{\prime \prime}$ to $82^{0}$ 02' 10" East longitudes. Climate of the study area is sub-humid tropical with average annual rainfall ranging between 1200-1400 $\mathrm{mm}$, of which $90 \%$ is received from south west monsoon during June-October (Kittur et al., 2014). The peak rainfall occurs in JulyAugust months. The mean temperature in January is about $21^{\circ} \mathrm{C}$ and in May temperature rises between $31^{\circ} \mathrm{C}$ and $41^{\circ} \mathrm{C}$. The mean annual temperature ranges from $21^{\circ} \mathrm{C}$ to $31^{\circ} \mathrm{C}$ (Kittur et al., 2014). The physiographic features ranges from flat to undulating slopes with small mountains, gorges scattered with trees and dense shrubs of natural vegetation. The soils of the area grouped into three classes viz., Inceptisols, Alfisols and Vertisols.

\section{Methods}

Reconnaissance survey was conducted in the study area, five forest types were identified on the basis of physiognomy and vegetation composition. The five types viz. Mixed forest, Mixed Sal forest, Teak Mixed forest, Mixed Teak forest and Bamboo brakes are distributed in the study area. Standing litter crop was recorded by randomly laying three $0.5 \times 0.5 \mathrm{~m}$ sub quadrates on the forest floor 
in each marked sample plot $(20 \times 20 \mathrm{~m})$ of a forest type. In total, standing litter was collected in 15 sample plots (3 locations within quadrate $\mathrm{x} 5$ quadrates) from each forest type and placed in labeled polyethylene bags and brought to the laboratory, where the samples were separated into leaf, wood, fruits, flower and bark components. Later the samples of separated components were dried at $80^{\circ} \mathrm{C}$ for three days and then their oven dry weights were determined. The weights of dried components were added together to derive the total standing litter mass of the respective sample plot of a forest type and the values were extrapolated to $\mathrm{Mg} \mathrm{ha}{ }^{-1}$ basis. Mean values of the litter of five sample plots represented the litter mass of that forest type.

Similar to standing litter, litter fall on the forest floor i.e litter input was also recorded in different seasons by randomly laying three litter traps $(0.5 \times 0.5 \times 0.5 \mathrm{~cm}$ size $)$ on the forest floor in each sample plot. In all, litter fall was carefully recorded in 15 sample plots (3 traps x 5 quadrates) in each season from different forest types. The litter was collected in three seasons (rainy, winter and summer) and placed in labeled polyethylene bags and brought to the laboratory, where the samples were separated into leaf, wood, twigs and bark components, later dried at $80^{\circ} \mathrm{C}$ for three days and determined the oven dry weights of collected samples. The weights of dried components were added together to derive total litter fall of respective sample plot of a given forest type and the data of three seasons was summed to obtain total annual litter fall, thereafter it was extrapolated on $\mathrm{Mg} \mathrm{ha}{ }^{-1}$ basis. Mean values of the litter fall of five sample plots represented the litter fall of that forest type.

\section{Statistical analysis}

Data on the standing litter and litter fall were analyzed in one-way analysis of variance in MS Excel. The significant difference between treatment means for all parameters were tested at $\mathrm{P}<0.05$ using least significant difference test (Gomez and Gomez, 1984).

\section{Results and Discussion}

\section{Standing litter floor biomass}

Standing litter (forest floor) mass varied significantly among components and also across the vegetation types (Table 1). Total standing litter ranged from $0.48 \mathrm{Mg} \mathrm{ha}^{-1}$ to $2.494 \mathrm{Mg} \mathrm{ha}^{-1}$ in different forest types. It was highest in Mixed Forest and lowest in Bamboo Brakes. The standing litter in different forest types followed the order: Mixed Forest > Mixed Sal Forest > Mixed Teak Forest $>$ Teak Mixed Forest $>$ Bamboo brakes. The litter mass contributed by different components was in the order: leaf > wood > bark and twigs. For total standing litter, the leaf litter contributed from $52.1 \%$ to $91.7 \%$, wood from $5.8 \%$ to $38.1 \%$ and bark litter from $1.4 \%$ to $12.1 \%$ in different forest types. The percent distribution within components across forest types revealed that percent contribution by leaves was highest in Bamboo brakes followed by Mixed Teak forest, Teak Mixed forest and Mixed Forest, while it was lowest in Mixed Sal forest. In contrast, the percent of wood component litter was highest in Mixed Sal forest and lowest in bamboo brakes. The bark and twigs contributed to highest percent in Teak Mixed forest and lowest in Mixed forest (Table 1).

\section{Litter fall}

Litter fall variations were found significant among components, across seasons and vegetation types. Seasonal variation in litter components across vegetation types are depicted through Figure 1-3. Litter fall was highest in the winter followed by summer and rainy seasons. Leaves contributed to maximum followed by wood and bark for total litter fall in different seasons. Total litter 
fall in the summer ranged from 0.39 to 1.29 $\mathrm{Mg} \mathrm{ha}{ }^{-1}$. It was highest in the Mixed Sal forest and lowest under bamboo brakes. For total litter fall in summer, the leaves contributed from $61.5 \%$ to $74 \%$, wood from $14.6 \%$ to $30.8 \%$ and bark litter from $5.4 \%$ to $11.5 \%$ (Fig. 1).

Similarly, litter fall in winter ranged from 0.38 to $1.39 \mathrm{Mg} \mathrm{ha}^{-1}$ (Fig. 2). It was highest in Mixed Sal Forest and the lowest in Bamboo Brakes. For total litter fall in winter, the leaves contributed from $52.3 \%$ to $89.4 \%$, wood from $8.1 \%$ to $37.61 \%$ and wood litter from $2.4 \%$ to $10.1 \%$ (Fig. 2). Total litter fall in the rainy season ranged from 0.2 to 1.07 $\mathrm{Mg} \mathrm{ha}{ }^{-1}$. It was highest in the Mixed Sal forest and lowest under bamboo brakes. For total litter fall in summer, the leaves contributed from $60 \%$ to $81.9 \%$, wood from $13.3 \%$ to $30.8 \%$ and bark litter from $4.8 \%$ to $10 \%$ (Fig. 3).

The total annual litter fall in different forest types ranged from 0.86 to $3.52 \mathrm{Mg} \mathrm{ha}^{-1} \mathrm{yr}^{-1}$ (Table 2). It was highest in Mixed Sal forest followed by Mixed Teak and Mixed Forests. It was lowest in Bamboo brakes. For total litter fall, in summer it ranged from $29.2 \%$ to $41.1 \%$, winter from $34.9 \%$ to $41 \%$ and rainy from $23.3 \%$ to $31.2 \%$ (Table 2).

Litter fall and litter decomposition have long been recognized as important processes that regulate carbon, nutrient pools and fluxes in tropical forests. The organic matter returned through litter fall influence physical, chemical and biological properties of soil. Litter fall has direct bearing on soil health and manipulates the growth and productivity of forests by regulating the supply of mineral nutrition. The standing litter and annual litter fall in the present study ranged from 0.48 to 2.49 $\mathrm{Mg} \mathrm{ha}^{-1}$ and 0.86 to $3.52 \mathrm{Mg} \mathrm{ha}^{-1}$, which are within the range and comparable to those recorded in dry tropical forests of India and world (Table 3). Hopkins (1966) recorded standing litter ranging from $0.50-4.8 \mathrm{Mg} \mathrm{ha}^{-1}$ and $1.80-5.50 \mathrm{Mg} \mathrm{ha}^{-1}$, respectively for 'dry' and 'moist' forests in Nigeria. Similarly, Bernhard (1970) observed standing crop of litter, which ranged even $<1 \mathrm{Mg} \mathrm{ha}^{-1}$ to $>3.5$ $\mathrm{Mg} \mathrm{ha}^{-1}$ in forests of Ivory Coast.

However, litter mass values observed in the present study were quite lower in comparison to Singh (1992) and Yadav (2018). Singh (1992) reported 4.88 to $6.71 \mathrm{Mg} \mathrm{ha}^{-1}$ annual litter fall in dry tropical forests of Vindhyan region of Uttar Pradesh. Climate is the major factor that influences the litter production. The relatively higher mean annual temperature with low rainfall in Vindhyan could be attributed for higher litter production, while the lower mean annual temperature and higher rainfall might be the possible reasons for low litter production in the present study area of Amarkantak Biosphere Reserve.

The present study also indicated the litter fall by components followed the order: Leaf $>$ Wood $>$ Bark \& Twigs. The results are in conformity with the findings of Singh (1992), where the leaf litter contributed from $65 \%$ to $72 \%$ and wood litter from $28 \%$ to $35 \%$, and remaining by bark and twigs to total annual litter fall. The present study also showed seasonal variation in the litter fall in the following order: Winter> Summer> Rainy.

The trends of litter fall patterns were similar and matched to those reported by earlier workers in different tropical forests (Brown and Lugo, 1982; Prasad and Mishra, 1985; Singh, 1992). The total litter fall in dry and wet tropical forests varied from 3-10 $\mathrm{Mg} \mathrm{ha}^{-1}$ and 5-14 $\mathrm{Mg} \mathrm{ha}^{-1}$, respectively (Murphy and Lugo, 1986). The total leaf litter production in these forests was found to be $4.96 \mathrm{Mg} \mathrm{ha}^{-1}$. Vituosek and Sanford (1986) had reported that total litter fall in tropical moist forest ranged from 3.6 to $12.4 \mathrm{t} \mathrm{ha}^{-1} \mathrm{yr}^{-1}$ (Fig. 3). 
Rai and Proctor (1986) estimated that the litter production of rain forest in Karnataka, India was in between 3.4 to $4.2 \mathrm{t} \mathrm{ha}^{-1} \mathrm{yr}^{-1}$. Singh (1992) observed the pattern of leaf and non-leaf fall and quantified the total annual return of litter in a dry tropical forest of India.

Total annual inputs of litter ranged between 4.88-6.71 $\mathrm{t} \mathrm{ha}^{-1}$ of which 65-72 percent was leaf litter fall and 28.35 percent wood litter fall. Numerous researchers have demonstrated litter fall biomass varied according to species composition, structure and climatic conditions (Tang et al., 2010; Wang et al., 2019; Wallis et al., 2019). The species composition seems to be important for litter production within the same climate range. In the present study, the higher litter fall was found in Sal Mxed and
Mixed forests, which could be attributed to the higher density, greater basal area and relatively high diversity compared to remaining forest types.

Previous studies have reported that litter fall productivity was higher in diverse mixed stands than those under monoculture stands (Tang et al., 2010; Wang et al., 2019; Yadav, 2018). The higher diversity, the greater densities and basal area in Mixed Forests might result in the higher litter production compared to monoculture Bamboo brakes and Teak forests (Darro et al., 2020). Our findings suggest that maintaining species diversity and density are important and could be effective means for restoring ecosystem processes by improving quantity and quality of litter mass.

Table.1 Standing litter biomass in vegetation types in Khuriya Forest Range of Mungeli Forest Division Chhattisgarh, India $\left(\mathrm{Mg} \mathrm{ha}^{-1}\right)$

\begin{tabular}{|r|l|c|c|c|c|}
\hline S. No. & Vegetation types & Leaf & Wood & Bark \& Twigs & Total \\
\hline 1 & Mixed Forest & 1.834 & 0.626 & 0.034 & 2.494 \\
\hline 2 & Mixed Sal Forest & 1.022 & 0.746 & 0.192 & 1.961 \\
\hline 3 & Mixed Teak Forest & 1.478 & 0.206 & 0.024 & 1.708 \\
\hline 4 & Teak Mixed Forest & 0.494 & 0.096 & 0.081 & 0.671 \\
\hline 5 & Bamboo Brakes & 0.441 & 0.028 & 0.011 & 0.481 \\
\hline & CD at 5\% & 0.34 & 0.37 & 0.11 & 0.62 \\
\hline
\end{tabular}

Table.2 Total litter fall carbon in vegetation types in Khuriya Forest Range of Mungeli Forest Division Chhattisgarh, India $\left(\mathrm{Mg} \mathrm{ha}^{-1}\right)$

\begin{tabular}{|l|l|c|c|c|r|}
\hline S. No. & Forest Type & Sumner & Winter & Rainy & Total \\
\hline 1 & Mixed Forest & 0.98 & 1.09 & 0.94 & 3.01 \\
\hline 2 & Mixed Sal Forest & 1.07 & 1.38 & 1.07 & 3.52 \\
\hline 3 & Mixed Teak Forest & 0.96 & 1.29 & 1.06 & 3.31 \\
\hline 4 & Teak Mixed Forest & 0.88 & 1.19 & 0.83 & 2.91 \\
\hline 5 & Bamboo Brakes & 0.36 & 0.3 & 0.2 & 0.86 \\
\hline & CD at 5\% & 0,25 & 0.30 & 0.49 & \\
\hline
\end{tabular}


Table.3 Comparative account of litter fall $\left(\mathrm{Mg} \mathrm{ha}^{-1} \mathrm{yr}^{-1}\right)$ in different tropical forest of the world

\begin{tabular}{|c|c|c|c|c|}
\hline S. No. & Forest types & Location & $\begin{array}{l}\text { Total litter biomass } \\
\left(\mathrm{Mg} \mathrm{ha}^{-1} \mathrm{yr}^{-1}\right)\end{array}$ & Source \\
\hline 1 & Tropical moist forest & & $3.6-12.4$ & $\begin{array}{l}\text { Vitousek and Sanford } \\
\text { (1986) }\end{array}$ \\
\hline 2 & Dry and Wet Tropical Forest & & $\begin{array}{l}3-10 \\
5-14\end{array}$ & Murphy and Lugo (1986) \\
\hline 3 & Rain Forest & Karnataka India & $3.4-4.2$ & Rai and Proctor (1986) \\
\hline 4 & Dry Tropical Forest & $\begin{array}{l}\text { Barnawapara } \\
\text { Sanctuary of } \\
\text { Chhattisgarh }\end{array}$ & 2.0 to 4.2 & Thakur et al., (2019) \\
\hline 5 & Dry Tropical Forest & $\begin{array}{l}\text { Khuriya Forest } \\
\text { Range (AABR) } \\
\text { Chhattisgarh }\end{array}$ & $0.78-3.66$ & Present study \\
\hline
\end{tabular}

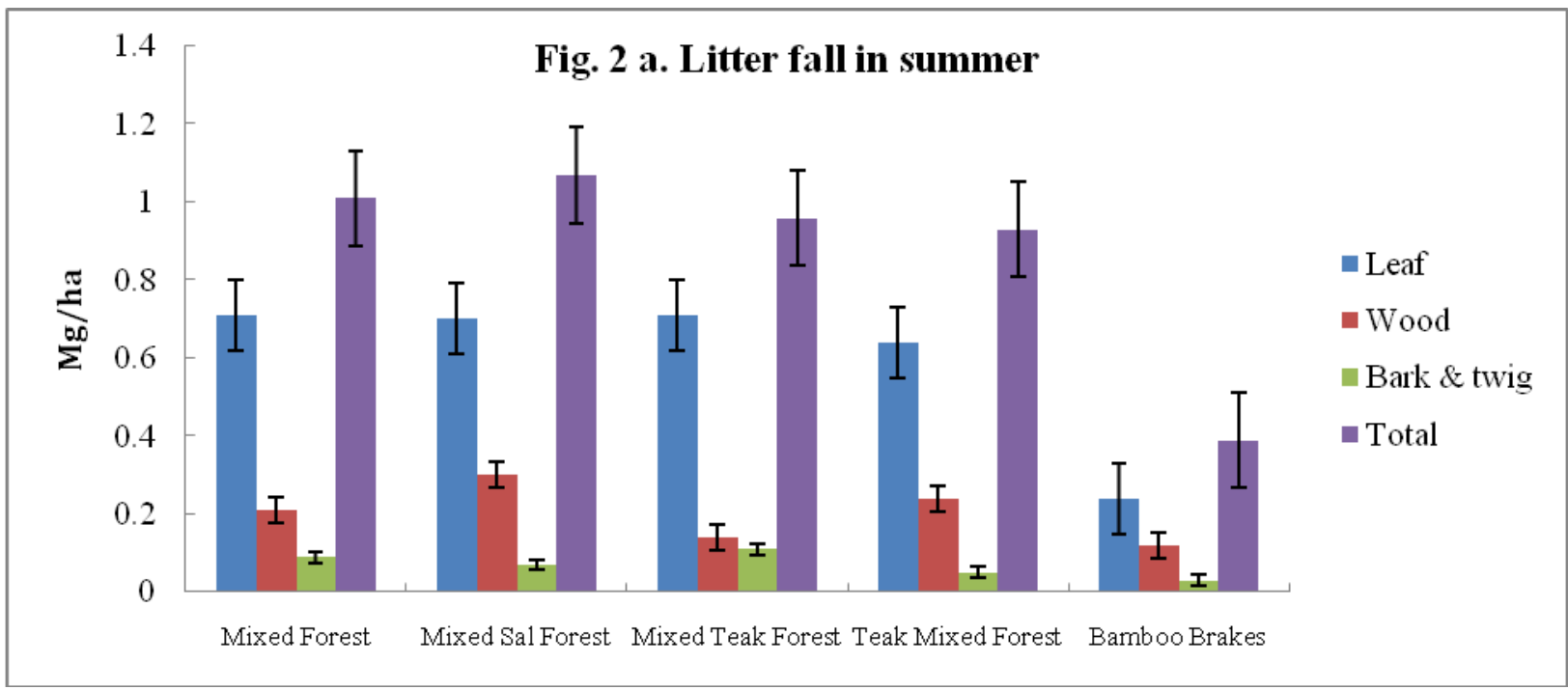

Fig.1 Litter fall in summer

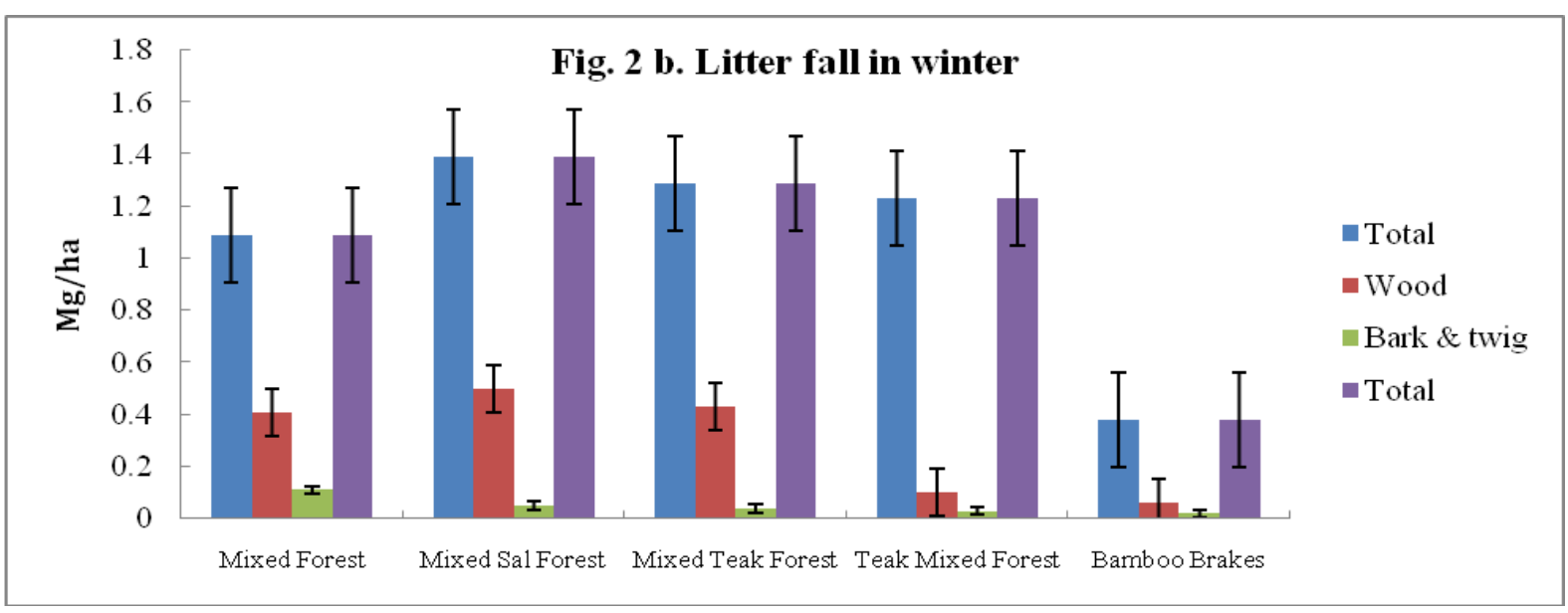

Fig.2 Litter fall in winter 


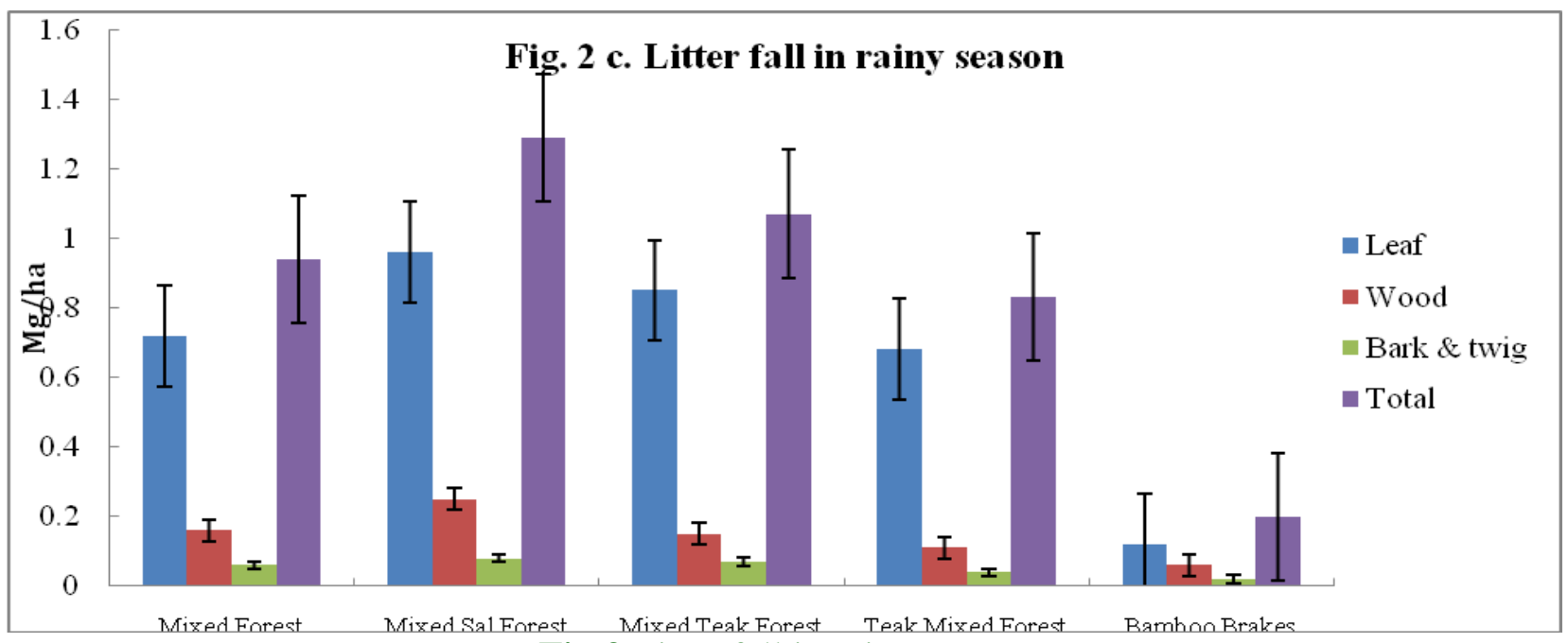

Fig.3 Litter fall in rainy season

Although, the present findings of the study corresponds to a limited period of 2 years but not enough to draw final conclusion, however they are indicative on the patterns of litter production under different forest types in buffer zone of AABR. The continuous data of litter fall for a long period of about 8-10 years along with biophysical conditions are needed for understanding litter dynamics and production.

The study clearly demonstrated that maintaining structure and diversity of vegetation are important for quantitative and qualitative litter production. The rehabilitation of degraded forests of Sal and Mixed forests by monoculture plantations of Teak and Bamboo are not ecologically desirable and negatively affect the litter production and cycling of nutrients.

Our findings suggest that establishing multispecies and multistorey man-made tropical forests could be an effective way to enhance litter productivity and maintain soil nutrients on degraded sites. It is suggested to introduce native species and minimize the biotic interferences to achieve the sustainable production of litter mass and efficient cycling of nutrients in tropical forest ecosystems.

\section{Acknowledgements}

Authors are thankful to Director Research Services, Indira Gandhi Agricultural University for providing necessary funds and facilities for conducting the research. The logistic support by Forest Staff, Khuria Range, Mungeli Forest Division, Chhattisgarh during investigation is duly acknowledged.

\section{References}

Bernhard, F. (1970). Étude de la litiére et desa contribution au cycle des elements minerauxen forêst ombiofile de Côte-d'-Ivoire. Oecol. Plant 5: 247266.

Brown, S. and Lugo, A.E. (1982). The storage and production of organic matter in tropical forests and their role in the global carbon cycle. Biotropica 14:161-187.

Brown, S., Therson, L.R. and Lugo, A.E. (1994). Land use and biomass changes of forests in peninsular Malaysia from 1972 to 1982: A GIS approach. Springer-verlag Jue. U.S. America.

Darro, H., Swamy, S.L., Thakur, T.K. and Mishra, A. (2020). Floristic Composition, Structure, Diversity and 
Conservation Strategies for Rehabilitation of Dry Tropical Forests in Buffer Zone of Achanakmaar Amarkantak Biosphere Reserve (AABR), India. Int. J. Curr. Microbiol. App. Sci. 9(04): xx-xx.

Gomez, K.A. and Gomez, A.A. (1984). Statistical procedure for agricultural research (Second edition). Wiley Inter Science Publication. New York.

Hopkins, B. (1966). Vegetation of the Olokemeji Forest Reserve Nigeria. IV. The litter and soil with special reference to their seasonal changes. $J$. Ecol. 54: 687-703.

Kittur, B. H., Swamy, S.L., Bargali, S.S. and Jhariya, M.K. (2014) Wildland fires and moist deciduous forests of Chhattisgarh, India: divergent component assessment. J. For. Res. 25(4): 857-866.

Murphy, P.G. and Lugo, A.E. (1986). Ecology of tropical dry rain forest. Ann. Rev. Ecol Syst. 17:67-88.

Nakagawa, M., Ushio, M., Kume, T. and Nakashizuka, T. (2019). Seasonal and long-term patterns in litterfall in a Bornean tropical rainforest. Ecol. Res. 34:31-39.

Prasad, R. and Mishra, G.P. (1985). Litter Productivity of Dry Deciduous Teak Forest Stands of Sagar (Madhya Pradesh). Ind For. 111(6):359-367.

Rai, S.N. and Proctor, J. (1986). Ecological studies on four rain forests in Karnataka. II. Litter fall. J. Ecol. 74:455-463.

Singh, L. (1992). Dry matter and nutrient inputs through litter fall in a dry tropical forest of

India. Vegetatio 98, 129-140.

Tang, J.W., Cao, M., Zhang, J.H. and Li, M.H. (2010). Litter fall production, decomposition and nutrient use efficiency varies with tropical forest types in Xishuangbanna, SW China: a 10-year study. Plant and Soil 335271-288.

Thakur, T., Swamy, S.L., Bijalwan, A. and Dobriyal, M. J. (2019). Assessment of biomass and net primary productivity of a dry tropical forest using geospatial technology. J For. Res. 30(1): 157-170.

Vitousek, P. M. and Sanford, R. L., 1986. Nutrient cycling in moist tropical forest. Ann. Rev. Ecol. Syst. 17:13767.

Wallis, C.I.B., Homeier, J., Pena, J., Brandl, R. and Farwig, N. (2019). Modeling tropical montane forest biomass, productivity and canopy traits with multispectral remote sensing data. Rem. Sen. Env. 225: 77-92.

Wang, G., Guan, D., Xiao, L. and Peart, M.R. (2019). Forest biomass-carbon variation affected by the climatic and topographic factors in Pearl River Delta, South China. J. Env. Manage. 232: 781-788.

Yadav, D.K. (2018). Litterfall Pattern and Forest Floor Biomass in Achanakmar Amarkantak Biosphere Reserve, India. Bull. Env. Pharmacol. Life Sci. 7 (6): 45-52.

\section{How to cite this article:}

Darro, H. and Swamy, S. L. 2020. Standing Litter and Litterfall Pattern in Dry Tropical Forests of Achanakmaar-Amarkantak Biosphere Reserve (AABR), India. Int.J.Curr.Microbiol.App.Sci. 9(04): 2000-2007. doi: https://doi.org/10.20546/ijcmas.2020.904.240 